Magdalena Jaś*

\title{
Greenhouse gas emission allowance trading scheme in the Polish law
}

\author{
http://dx.doi.org/10.12775/PYEL.2012.007
}

\section{Introduction}

Struggling with climate change is the top priority for the European Union. The Emission Trading Scheme constitutes the most important pillar of the EU climate policy and the aim of this instrument is to reduce pollution emissions. The Emission Trading Scheme is the implementation of the Kyoto Protocol ${ }^{1}$ and the fulfilment of obligations resulting from Poland's European Union membership. The Kyoto Protocol on Climate sets legally binding reduction commitments and schedules for reduction of greenhouse gas emissions for each country ${ }^{2}$.

* Master of Law, Public Economic Law Department, University of Gdańsk.

1 Protocol Kyoto to the United Nations Framework Convention on Climate Change, http://unfccc.int/resource/docs/convkp/kpeng.pdf.

2 Detailed Analysis of Kyoto Protocol: S. Clo, European Emissions Trading in Practice, An Economic Analysis, Cheltenham 2011, p. 9-33; T. J. Bishop (ed.), Global environment and Climate Change, Nova Science Publishers New York 2011. 


\section{Magdalena Jaś}

Countries-parties are obliged to implement legal instruments that contribute to achieving their reduction targets. In order to support the national activities, the Kyoto Protocol allows countries-parties to participate in the complementary mechanisms of emission reduction or to increase the absorption of greenhouse gases, which is less expensive in other countries. Kyoto Mechanisms are the Joint Implementation ${ }^{3}$, Clean Development Mechanism ${ }^{4}$ and International Emissions Trading. They support the countries in reaching their target greenhouse gas emission levels. Countries having their targets set can invest in environmental projects in developing countries. Countries-parties can acquire emission reduction units (ERUs), certified emission reduction units (CERs) ${ }^{5}$, assigned amount units (AAU) and removal units (RMUs) from other countries-parties. Acquired units can be used to achieve the reduction targets. This allows countries-parties to use less expensive emission reduction methods in order to reduce the overall cost of limitations.

The European Union leads global efforts to reduce greenhouse gas emissions which may lead to dangerous changes in the world's climate. Emissions trading, which allows for the reduction of emission level, is the key instrument used to prevent climate change and it is commonly considered as one of the most market-oriented instruments. It was introduced in the European Union and many other countries ${ }^{6}$. Poland signed the United

3 Joint Implementation (JI) is defined in Article 6 of the Protocol; The mechanism allows a country with an emission reduction or limitation commitment under the Kyoto Protocol (Annex I Party) to earn emission reduction units (ERUs) from an emissionreduction or emission removal project in another Annex I Party, each equal one tonne of $\mathrm{CO} 2$, which can be calculated towards meeting its Kyoto target.

4 Clean Development Mechanism (CDM) is defined in Article 12 of the Protocol. According to Article 12(3): "Under the clean development mechanism:

(a) Parties not included in Annex I will benefit from project activities resulting in certified emission reductions; and

(b) Parties included in Annex I may use the certified emission reductions accruing from such project activities to contribute to compliance with part of their quantified emission limitation and reduction commitments under Article 3, as determined by the Conference of the Parties serving as the meeting of the Parties to this Protocol."

5 P. Dombrowicki, A. Gałan, Wykorzystywanie jednostek CER/ ERU w EU ETSAnaliza sytuacji w Polsce, Warszawa 2010, http://www.kobize.pl/materialy/opracowania/ grudzien2010/offset_EU_ETS_PL_29_12_2010_czysty.pdf.

6 J. Baran, A. Janik, A. Ryszko, Handel emisjami w teorii i praktyce, Warszawa 2011, p. 31. 
Nations Framework Convention on Climate Change ${ }^{7}$ and ratified the Kyoto Protocol, at the same time undertaking to reduce greenhouse gases emission.

\section{European Union Emission Trading System}

Since Green Paper on greenhouse gas emissions trading within the European Union $^{8}$ was published in 2000, it has started the debate on a uniform legislative act allowing the actual introduction of the emission trading system in the EU. The European Union Emission Trading System (further referred to as the EU ETS) was designed in 2003 and officially launched in 2005. The initial directive governing the system was issued in 2003. The Directive 2003/87/EC of the European Parliament and of the Council of 13 October 2003 establishing a scheme for greenhouse gas emission allowance trading within the Community and amending the Council Directive 96/61/EC ${ }^{9}$ introduced an economical mechanism known as mission allowances trading scheme.

The Directive 2003/87/EC was further amended. The first amending Directive was the Directive 2004/101/EC of the European Parliament and of the Council of 27 October 2004 amending the Directive 2003/87/EC establishing a scheme for greenhouse gas emission allowance trading within the Community, in respect of the Kyoto Protocol's project mechanisms ${ }^{10}$. The next amendment was introduced by the Directive 2008/101/EC of the European Parliament and of the Council of 19 November 2008 amending the Directive 2003/87/EC so as to include aviation activities in the scheme for greenhouse gas emission allowance trading within the Community ${ }^{11}$, as well as the Directive 2009/29/EC of the European Parliament and of the Council of 23 April 2009 amending the Directive 2003/87/EC so as to

7 The United Nations Framework Convention on Climate Change, 1992; http://unfccc. int/resource/docs/convkp/conveng.pdf

8 COM/2000/0087 final, Brussels, 08.03.2000.

9 Directive 2003/87/EC of the European Parliament and of the Council of 13 October 2003 establishing a scheme for greenhouse gas emission allowance trading within the Community and amending Council Directive 96/61/EC, OJ (2003) L 275/32.

10 OJ L 338 of 13.11 .2004 , p. 18.

11 OJ L 8 of 13.01.2009, p. 5. 
improve and extend the greenhouse gas emission allowance trading scheme of the Community ${ }^{12}$.

The EU ETS is a company-level 'cap-and trade' system of allowances for emitting carbon dioxide (CO2) and other greenhouse gases. That means there is a 'cap' (or limit) on the total amount of certain greenhouse gases that can be emitted by installations in the system. This system sets up a market where allowances can be sold and acquired by operators ${ }^{13}$. If an installation emits more gases than prescribed by the number of allowances it holds in the registry, it has to purchase more allowances on the market.

Emission allowances are granted to entities covered by the system for a certain period. Phase I was carried out between 2005 and 2007. It was a three-year pilot phase of learning. During that period the price of carbon was established, as well as the free trade in emission allowances across the $\mathrm{EU}$ and the necessary infrastructure for control and reporting ${ }^{14}$. Phase II began in 2008 and it was due to end in 2012. During this period, installations operators received allowances distributed on the basis of national allocation plans.

Phase III is going to last from 2013 to 2020. It is planned to encourage long term investments in emissions reductions during this period. Based on the experience from previous periods, some changes are going to be introduced. So far, allowances are distributed between the Member States as follows:

- by free allocation,

- by auctioning.

From the beginning of Phase III of the EU Emissions Trading System (2013-2020), the power sector will have to buy all its allowances (auctioning). However, Poland like nine other Member States, can choose to allocate a limited number of free allowances to power stations. Poland has made considerable progress in energy efficiency in the past 20 years, although Poland's energy industry is dominated by coal.

12 OJ L 140 of 5.06.2009, p. 63.

13 J. Baran, A. Janik, A. Ryszko, Handel emisjami..., p. 25-30.

14 Further: S. Okinczyc, European Emissions Trading Scheme: Phase III, European Energy and Environmental Law Review, August 2011, p. 164-173. 


\section{Legal basis of the regulations in Poland}

The EU ETS law was implemented into the Polish law. The basic legal act on emission allowance trading in Polish legal system was the Act of 22 December 2004 on Greenhouse Gas and Other Substances Emission Allowance Trading. Currently, the basic legal acts are:

- the Act of 28 April 2011 on Greenhouse Gas and Other Substances Emission Allowance Trading Scheme ${ }^{15}$ (further referred to as the ETS Act),

- the Act of 17 July 2009 on Management of the Emissions of Greenhouse Gases and Other Substances ${ }^{16}$ (further referred to as the MEG Act).

The ETS Act supersedes the Act of 22 December 2004 on Greenhouse Gas and Other Substances Emission Allowances Trading. The Act of 2004 has proven that there is a need to clarify legal rules with regard to implementation of the Directive 2003/87/EC and further Directives. The ETS Act introduces significant changes to the sector. The law implements provisions relating in particular to the qualification of installations covered by the scheme. The installation is defined in article 3(6) of the Act of 27 April 2001 on Environmental Protection Law ${ }^{17}$ (further referred to as the EPA). The ETS Act also introduces the rules for disposal of emission allowances, the terms for auctioning and the system of effective sanctions securing the performance of obligations imposed by the law.

What is new in the ETS Act is the introduction of a system of air operations to be made by aircraft operators, who arrive at Member States airports or depart from them. The new law regulates the functioning of the scheme of aircraft operations performed by aircraft operators. The incorporation of aviation emissions in the EU ETS is one of the major developments in the EU ETS Phase III ${ }^{18}$. The new ETS Act covers the new regulations which were due to be introduced under the obligation to implement the new Directives.

15 Journal of Laws of 2011, No 122, item 695.

16 Journal of Laws of 2009, No 130, item 1070 with amendments.

17 Journal of Laws of 2008, No 25, item 150 with amendments.

18 S. Okinczyc, European Union Emissions Trading Scheme: Phase III, European Energy and Environmental Law Review, August 2011, p. 170. 


\section{Magdalena Jaś}

The ETS Act of needs to be amended to comply with the allowance trading system rules, which will apply in the European Union starting from 1 January 2012. Currently the new law transposing EU legislation of the trading scheme for greenhouse gas emissions is being developed.

The MEG Act is an element of regulation relating to the reduction of emissions of greenhouse gases and other substances. It has filled the gap of a systemic regulation in the Polish national legal system. The law introduces solutions which allow Poland to fulfil international commitments in respect of:

- reduction of emissions of greenhouse gases and other substances,

- registration of gas emissions,

- reporting the volume of pollutants emitted into the atmosphere ${ }^{19}$.

The MEG Act established a national emissions balancing and management system, which organises all data on the quantity of emissions of greenhouse gases and other substances.

The executive acts of a vital role for emissions trade in Poland are:

- regulation of the Minister of the Environment of 25 July 2011 on information required for preparation of national allocation plan $^{20}$,

- regulation of the Minister of the Environment of 10 November 2010 on reports on the control of Joint Implementation and reports on verification of number of reduction of emissions units created as part of Joint Implementation Project ${ }^{21}$,

- regulation of the Government of 1 July 2008 on acceptance of the National Allocation Plan for 2008-2012 for emission allowance trading scheme ${ }^{22}$,

- regulation of the Minister of the Environment of 27 September 2011 on percentile contribution of emission allowance in accounting period starting on 1 January 2013 which may be granted to installations covered by emission allowance trading scheme ${ }^{23}$,

- regulation of the Minister of the Environment of 3 December 2010 on specified range of information included in project documentation ${ }^{24}$,

19 Justification to the Act of 17 July 2009 on Management of the Emissions of Greenhouse Gases and Other Substances.

20 Journal of Laws of 2011, No 154, item 914.

21 Journal of Laws of 2010, No 225, item 1472.

22 Journal of Laws of 2008, No 202, item 1248.

23 Journal of Laws of 2011, No 203, item 1194.

24 Journal of Laws of 2010, No 240, item 1608. 
- regulation of the Minister of the Environment of 12 September 2008 on means of controlling of the amounts of emission of substances covered by emission allowance trading scheme ${ }^{25}$,

- regulation of the Government of 20 October 2009 on the types of programs and projects allocated for national system of green investments ${ }^{26}$,

- regulation of the Minister of the Environment of 5 August 2010 on defining form, structure and scope of information included in reports on programs and projects implemented in the national system of green investments ${ }^{27}$,

- regulation of the Minister of the Environment of 26 August 2010 on the types of undertakings which may be implemented as Joint Implementation Projects in the territory of the Republic of Poland ${ }^{28}$,

- regulation of the Minister of the Environment of 25 October 2010 on the motion for creation of the letter supporting the Joint Implementation Project ${ }^{29}$.

\section{The material scope of the act of 28 April 2011 on the greenhouse gas and other substances emission allowance trading scheme}

The ETS Act lays down the rules for operation of greenhouse gas emissions trading. The material scope of the trading scheme for greenhouse gases emission allowance covers for the following types of emissions:

1) greenhouse gas emissions from the installations carrying out activities causing emissions if the installations meet the requirements. Greenhouse gas emissions from the installations meeting the requirements,

\footnotetext{
5 Journal of Laws of 2011, No 154, item 914.

Journal of Laws of 2009, No 187, item 1445.

Journal of Laws of 2010, No 152, item 1027.

Journal of Laws of 2010, No 167, item 1132.

Journal of Laws of 2010, No 213, item 1406.
} 
2) greenhouse gas emissions from aircraft operations which start or end within the territory of a Member State.

According to the Act, greenhouse gas emissions from installations covered by the system apply from 1 January 2008 to 31 December 2012 only for carbon dioxide (CO2). However, since 1 January 2013, the emission of greenhouse gases from installations covered by the system also applies (except carbon dioxide) to other greenhouse gases: nitrous oxide (N2O), and perfluorocarbons (PFCs). In the case of aircraft operations, greenhouse gas emissions from 1 January 2012 apply only for carbon dioxide (CO2).

The discussed Appendix defines:

- types of installations and threshold values for production abilities of these installations, as well as types of activities run using installations covered by the system during the accounting period of 2008-2012;

- types of installations covered by the system or types of activities run using installations covered by the system, during the accounting period starting on 1 January 2012, as well as threshold values for production abilities of these installations and activities, along with greenhouse gases corresponding to a given installation or type of activity;

- global warming potentials of the greenhouse gases.

\section{The supervision of the Minister of the Environment}

The system is supervised by the Minister of the Environment. This kind of supervision is understood as the control and authority to intervene, which ensures good operation of the whole system. The measures of supervision used by the Minister of the Environment on the management and functioning of the emissions system, including the emission allowance trading scheme, have been defined by the MEG Act.

Article 5 of the MEG Act regulates relationship between the Minister of the Environment and the National Centre for Emissions Balancing and Management (KOBIZE). The Minister of the Environment supervises the performance of the National Centre's duties. By 31 January of each year, the National Centre submits a report on its performance in the previous calendar year to the Minister of the Environment. If the report is incomplete or provides grounds to objections, the Minister of the Environment may request that the report is supplemented or additional clarification is provided. 
If the National Centre fails to submit the report or the required justification by a given date, or if the submitted report provides grounds to objections, the Minister of the Environment may request that an inspection of the National Centre's performance is carried out by competent agencies.

If the inspection reveals any significant irregularities in the performance of the National Centre, the Minister of the Environment may dismiss the Director of the Institute of Environmental Protection before the end of their tenure, without requesting for the opinion referred to in article 22(1) of the Act of 25 July 1985 on Research and Development Establishments.

The Minister of the Environment is the superior authority to the bodies performing public duties arising from the Act. The competence for issuing permissions for participation in the system is given under the Act to the authorities of local government (marszałek, starosta).

\section{Administration of allowances}

According to article 7 of the ETS Act, trading system emission allowance of greenhouse gases regulates the operation of the National Centre for Emissions Balancing and Management (further referred to as KOBIZE). KOBIZE was created under the provisions of the Act of 17 July 2009 on the Management of Emission of Greenhouse Gases and Other Substances. National Centre took over the tasks of the National Administrator of Emissions Trading System (KASHUE) established under the Act of 22 December 2004 on Trade of Emission Allowance of Greenhouse Gases and Other Substances. According to article 4 of the MEG Act, the performance of duties of the National Centre is a responsibility of the Institute for Environmental Protection in Warsaw. It is a research institute supervised by the Minister of the Environment under the provisions of Chapter 7 of the Act of 30 April 2010 on Research Institutes. ${ }^{30}$

The scope of work of the National Centre for Balancing and Emissions Management is covered by Article 3(2) of the MEG Act. The role of the National Centre is as follows:

30 Journal of Law of 2010, No 96, item 618 with amendments. 
1) carrying out tasks relating to the operation of the National System for Emission Balancing and Forecasting, including the keeping of the National Database on Emissions of Greenhouse Gases and Other Substances;

2) keeping the National Registry of the Kyoto Units and emission allowance;

3) providing opinions on the requests for the issuance of the Letter of Endorsement and the requests for the issuance of the Letter of Approval for the Joint Implementation Projects to be carried out on the territory of the Republic of Poland;

4) keeping the list of the Joint Implementation Projects carried out on the territory of the Republic of Poland for which the Letters of Endorsement or the Letters of Approval have been issued;

5) keeping the list of entities authorised to verify the reports on greenhouse gas emission reductions achieved within the framework of the National Green Investment Scheme or the Joint Implementation Projects and drawing up the reports referred to in article 40(7)(2);

6) drawing up reports and forecasts on emission levels;

7) developing the methods of determining emission levels for particular types of installations or activities and the methods of determining emission factors per unit of manufactured product, fuel consumed or raw material used;

8) developing the emission factors per unit of manufactured product, fuel consumed or raw material used;

9) control of carrying out the Joint Implementation Projects and Projects of Clean Development Mechanism as well as other projects aiming at evasion or reduction of greenhouse gas emissions;

10) management of emission allowance trading system, in particular:

a) keeping electronic database storing information about installations covered by the system, needed for the emission allowance distribution for installations covered by the system, as well as the register mentioned in article 21(2) of the ETS Act, and controlling the performance of obligations by entities owning installations, observance of fulfilling obligations connected with membership in the system by subjects conducting installations

b) keeping electronic database of information on aircraft operators performing air operations necessary to control the performance of obligations by aircraft operators being members of the system, 
c) providing opinions on controlling plans, mentioned in article 51(1) of the ETS Act

d) gathering data and preparing analyses of the system

e) preparing the project of national plan for division of emission allowance for installations covered by the system and register mentioned in article 21(2) of the ETS Act,

f) drawing up reports on the system as regards membership in installation system and aircraft operators,

g) providing information and training materials as well as giving trainings on the functioning of the system,

h) cooperation with administrative authorities in the area of system functioning and fulfilling international obligations arising from the membership in the system,

i) keeping register of units allowed for reports verification defined in Emissions of Greenhouse Gas Allowance Trading System Act of the ETS Act,

j) holding auctions for emission allowance,

k) providing opinions at the request of the Minister of the Environment, drafts of legal acts and documents on the functioning of the system,

1) drawing up registers of entities using installations and aircraft operators who breached the obligations arising from the membership in the system and handing them over to the Minister of the Environment ${ }^{31}$.

The National Centre also provides summaries and reports, in particular for the purposes of official statistics, the list of charges for gas and dust emitted into air, balancing the system of greenhouse gas emissions, the emissions of sulphur dioxide $\left(\mathrm{SO}_{2}\right)$ and nitrogen oxides $\left(\mathrm{NO}_{\mathrm{X}}\right)$ for large combustion plants, reporting under the greenhouse gas emissions trading scheme, the current air quality assessment including model analyses. The role of the National Centre can also involve providing another information and reports for public administration and organizations of local businesses and employer organizations.

The role of the National Centre also involves keeping the National Registry of the Kyoto Units and emission allowances. Due to this the national law will reflect the institution of consolidated register in which all

31 Article 3 (2) of Act of 17 July 2009 on management of emissions of greenhouse gases and other substances. 
types of units arising under the Kyoto Protocol mechanisms and emission allowances are being kept, which has qualified form assigned amount units (AAUs). Emission allowances arising from the assigned amount units conversion are distributed by entities participating in the system of emissions trading. Emissions permissions (occurring in trade between the participants in the community trading system) are a part of the balance of Kyoto units. ${ }^{32}$

\section{Distribution of emissions}

The distribution of emission allowances covered by the system is followed in the National Allocation Plan (further referred to as the NAP). Poland like each Member State has to develop an Allocation Plan for each ETS Phase. The national Centre prepares a draft of the National Allocation Plan ${ }^{33}$. The public can participate in the process of drawing up of the $\mathrm{Plan}^{34}$. After public consultations the National Centre forwards the draft of a national plan to the Minister of the Environment. The Minister consults the project with the Council of Ministers. The national plan is presented to the European Commission and the Member States. The Commission assesses the Member States' proposed NAPs against the allocation criteria listed in the Directives. The National plans have to be consistent with the EU's and Member States' Kyoto commitments, with the actual verified emission levels reported in the Commission's annual progress reports and with the technological potential to reduce emissions ${ }^{35}$.

According to article 13(1) of the ETS Act national allocation plans determine:

32 Justification of the draft of Act of 28 April 2011 on the greenhouse gas and other substances emission allowances trading scheme, p.8.

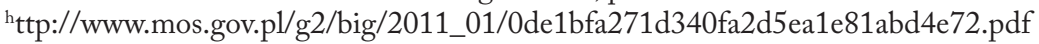

33 Article 14 (1) of the ETS Act.

34 Article 14 (2) ETS Act in connection to Act of 3 October 2008 on the Provision of Information on the Environment and its Protection, Public Participation in Environmental Protection and Environmental Impact Assessments, Journal of the Laws 2008 No 199 item 12277 with amendments.

35 Further about NAP from 2005-2007 ( about Organization, main phases, methodology and ETS share) in: B. Jankowski [in] A.D. Ellerman, B. K. Buchner, C. Carraro (ed.), Allocation in the European Emissions Trading Scheme, Poland, p. 306-307. 
1) the total quantity of emission allowances available for distribution in a commitment period;

2) the total quantity of emission allowances for particular types of installations covered by the system;

3) installations covered by the system along with the quantity of allocated emission allowances for each year;

4) the quantity of emission allowances which in the commitment period will constitute a national reserve of emission allowances for new installations and for those installations whose system was changed, referred to as 'national reserve';

$5)$ the quantity or percentage of emission reduction units and certified emission reductions units whose installations may be used to settle the annual emission level and the use of these units in the commitment period;

6) the quantity of emission allowances representing a reserve for JI projects with letter of approval, which help to reduce the level of carbon dioxide (CO2) emissions in installations covered by the system.

Approval of the Plan by the Commission opens the way for Poland to allocate its emission allowances. The Council of Ministers adopts the National Allocation Plan. At this point the nature of the national plan needs to be discussed. The national emission allocation plan is approved by a decree. According to the judgement of the Supreme Administrative Court (NSA) of 5 November $2011^{36}$, the decree cannot be the subject of a complaint to an administrative court, even though it includes individualspecific standards, relevant to the administration decision. In the judgement it was further defined that a decree as a form of legislation should be interpreted as a law-making activity. In the sentence it was emphasized that the decree, as a form of legislation, should be interpreted as a law-making activity aimed at the formation of the legal system.

The opinions vary on whether the Regulation in this meaning has a constitutive or rather declaratory character. The constitutive character of the Regulation reveals itself in the case of the entities whose installations are defined in the Regulation according to duties and entitlement to the emissions whereas the declaratory character is visible at the stage of defining

36 II OSK 1199-1109, published in LEX No. 628882. 
the range of entities whose installations are covered by the system under the law in compliance with the Appendix to the Act on Greenhouse Gas and Other Substances Emission Allowances Trading Scheme ${ }^{37}$.

According to the National Allocation Plan, the case Poland vs. the Commission should be submitted for approval of the National Allocation Plan for the years 2008-2012. The Republic of Poland notified the Commission of the European Communities, in accordance with Article 9(1) of the Directive 2009/29/EC ${ }^{38}$, of its National Allocation Plan for the period of 2008-2012. On 26 March 2007 the Commission adopted the Decision ${ }^{39}$ on the Polish NAP. The Commission concluded, essentially, that several criteria of the Directive had been infringed, and thus reduced the total annual quantity of emission allowances. In its Decision the Commission has not in any way indicated the data which were deemed less reliable. Similarly, the Commission has not explained in what way the data entered in the NAP were unreliable. It merely stated that they had not been verified in an independent and coherent manner. It should be noted that the Republic of Poland states that the data entered in the NAP had been the subject of a report within the framework of the UNFCCC and had therefore been surveyed by the Commission. Poland brought an action for annulment of these decisions, claiming that the Commission has exceeded its powers in rejecting NAPS.

By the judgement of 23 September $2009^{40}$ the Court decided that, 'having regard to the margin of manoeuvre enjoyed by Member States in drawing up their NAPs, by setting aside in that way the method of economic analysis used by the Republic of Poland and the data entered in the NAP, the Commission infringed the obligation to state reasons for the contested decision. ${ }^{41}$ In the conclusion, the Court agrees that national authorities are allowed to amend their NAPS at any time.

37 Karski L., Komentarz do ustawy System handlu uprawnieniami do emisji gazów cieplarnianych, Komentarz do art. 13 ustawy, Lex 2012.

38 Directive 2009/29/EC of the European Parliament and of the Council of 23 April 2009 amending Directive 2003/87/EC to improve and extend the greenhouse gas emission allowance trading scheme of the Community.

39 C(2007) 1295 final.

40 Judgement of the Court of First Instance, 23 September 2009, in Case T-183/07 Poland vs. Commission, OJ C 267 of 07 November 2009.

41 Judgement of the Court of First Instance, 23 September 2009, in Case T-183/07 Poland vs. Commission, OJ C 267 of 07 November 2009, http://curia.europa.eu/juris/ 
It should be noted that starting from 2013 auctioning will become the basic way of granting allowances in Europe, replacing the current system, in which the vast majority of allowances are given away for free by governments. Auctions will be held at the national level ${ }^{42}$. This change reflects the fact that auctioning system provides a stronger incentive for businesses to take early action to reduce emissions. Auctioning also complies better with the 'polluter pays' principle. Despite the planned change in the distribution of allowances by auctioning, Poland continues to receive some allowances for free. An exception for the general rule applicable to the power sector is laid down in Article 10(c) of the revised EU ETS Directive, which provides for the option of allocating a limited number of free allowances to power generators for a transitional period. In September 2011 Poland submitted applications for temporary free allocations for the power sector. The European Commission has approved Poland's request for a continued free allocation of EU Emissions Trading System (EU ETS) allowances to its power sector.

Number of allowances to be allocated for free to power plants in Poland in the following years:

\begin{tabular}{|c|c|c|c|c|c|c|c|c|c|}
\hline & 2013 & 2014 & 2015 & 2016 & 2017 & 2018 & 2019 & 2020 & Total \\
\hline PL & $77,817,376$ & $72,258,992$ & $66,700,608$ & $60,030,547$ & $52,248,809$ & $43,355,395$ & $32,238,627$ & 0 & $404,650,354$ \\
\hline
\end{tabular}

Polish power plants and CHP (Combined Heat and Power) plants can emit, for free' for seven years, 404650354 tons of CO2, with over 77 million in 2013. Every year the amount of free allowances will decrease (reaching zero in 2020). However, the European Commission has set certain conditions and modifications. ,The modifications Poland is required to make relate to installations which otherwise may not receive free allowances and to some technical aspects of allocation methodology used. The modifications need

document $/$ document.jsf ?text $=\&$ docid $=77652 \&$ pageIndex $=0 \&$ doclang $=$ EN\&mode $=$ doc $\&$ $\operatorname{dir}=\& o c c=$ first $\&$ part $=1 \&$ cid $=41985$.

42 Further: C/M/S Cameron McKenna, Phase III of the EUEmissions Trading Scheme: your QE'A guide, http://www.cms-cmck.com/Hubbard.FileSystem/files/Publication/91363aa90327-4e2e-823d-02a825c00c31/Presentation/PublicationAttachment/e72356ac-0b394ee1-84b9-3d5ce77f32c3/2020_Phase\%20III.pdf, accessed 18.07.2012. 
to be notified by the end of $2012^{\prime 43}$. The equivalent of free allowances should be invested in 'modernization of energy infrastructure of the country'.

\section{Greenhouse emission permit}

Entities using installations covered by the system are obliged to obtain permission for emissions of greenhouse gases. Permissions are granted at the request of an entity by the chairman of the management board of powiat (starosta) or of a voivodeship (marszałek) competent for issuing an integrated permission or allowance for emission of gases or liquids into air. The lack of such a permission means that using an installation in the area of emission of greenhouse gases covered by the system during the accounting period is not permitted. Under article 3(16) of the Act on Greenhouse Gas and Other Substances Emission Allowances Trading Scheme, a permission is an administrative decision allowing for emission of greenhouse gases from an installation covered by the system and defining duties of an entity using the installation as regards control.

\section{Emission amount control and accounting}

Control is crucial in the emission allowance trading system. The assessment of the amount of emissions and comparison of the measurements (with the use of the proper methodology) is the base for country's creation of the stabilized market of emissions. Carrying out complete, coherent, transparent and accurate controlling and reporting on emission of greenhouse gases is fundamental for proper functioning of the system. Detailed rules for controlling are set out by the Regulation of the Minister of the Environment of 12 September 2008 on means of controlling amounts of emission of substances covered by emission allowance trading scheme ${ }^{44}$.

43 Press releases of Commission, Emissions trading: Commission rules on temporary free allowances for power plants in Poland http://europa.eu/rapid/pressReleasesAction.do?r eference=MEMO/12/561\&format=HTML\&aged=0\&language $=$ PL\&guiLanguage=pl 
According to article 56 of the Act of 28 April 2011, an entity using an installation covered by the system is obliged to create the plan of emission amount control. Such an entity draws up the plan independently and the competent body can only accept or reject the plan. It is significant that acceptance of the control plan is a part of granting the permission.

Under article 43(2) of the ETS Act, along with the application for permission, the plan of emission amount control drawn up in a paper and electronic form should be enclosed among other required documents. For that reason there is no possibility to accept the plan of control in separate administrative decision ${ }^{45}$. Article 56(3) of the ETS Act stipulates the situation in which an entity carrying out an installation is obliged to change the emission amount control plan.

The Act of 28 April 2011 introduces separate regulations for control plan for air operations. The control plan prepared by an aircraft operator consists of set of information about the manner of running the register and data gathering for preparation of the annual report on $\mathrm{CO} 2$ emissions and balance of tonne- kilometre in a given accounting year ${ }^{46}$. The aircraft operator is obliged to prepare two separate control plans: the emission amount control plan and control plan for the amount of tonne-kilometres made during the air operations. The Act in the matter of the content of the control plan, directly refers to the decision of the Commission 2009/33/ $\mathrm{EC}^{47}$. In this act the requirements connected with content of prepared control plans and conducting inventory of data for air operators were defined.

The acceptance of a control plan drawn up by an aircraft operator differs from the acceptance of the installation emission control plans. An aircraft operator is obliged to issue a motion for the acceptance of the plan by the Minister of the Environment. The Minister hands over control plans to the National Centre for the purpose of checking their consistency with the

45 L. Karski, Komentarz do ustawy System handlu uprawnieniami do emisji gazów cieplarnianych, Komentarz do art. 56 ustawy, Lex 2012.

46 P. Maliński, M. Sekuła, Podstawowe informacje o wspólnotowym systemie handlu uprawnieniami do emisji dla operatorów statków powietrznych, Warszawa 2009, http://www. kobize.pl/materialy/lotnictwo/Przewodnik_dla_operatorow_lotniczych_final_03112009. pdf.

47 Commission Decision of 16 April 2009 amending Decision 2007/589/EC as regards the inclusion of monitoring and reporting guidelines for emissions and tonne- kilometre data from aviation activities, OJ L 103 of 23.4.2009, p. 10. 
Commission's decision 2009/29/EC. Subsequently the National Centre informs the Minister of the compliance of the plans within 14 days from receiving such plans. The Minister accepts the control plans by issuing a decision.

\section{Auctions}

According to article 29 of ETS Act, allowances which will not be used until 31 December 2012 may be disposed of at the auction. These may come from:

- national reserve (with the exception of allowances to be transferred to national reserve as a result of national plan change)

- reserves for emission allowance for JI projects with approval list, which cause a reduction of carbon dioxide (CO2) emissions in installations covered by the system referred to the Article 13 (1)(6) of the ETS Act.

Significantly, the total amount of emission allowances sold at the auction cannot exceed $10 \%$ of the total amount of emission allowances available for distribution in the reference period of 2008-2012. Pursuant to the EU regulations, auctions will be the main system used starting from 2013. Auctioning has not been regulated by the Polish law yet. The principles of disposal of emission allowances are one of the points to be defined in the new Act. Although Poland has received certain limit of free allowances there will be still a need to purchase more. The outstanding allowances can be purchased inter alia at the auction, by purchasing units of the Kyoto mechanism or used with emission allowances savings. New among other things, the new Act will regulate the usage of the capital earned from the sale of allowances.

\section{Conclusions}

The Republic of Poland as a Member State of the European Union should respect the EU regulations. Although there are some restrictions to free development of the emission trading system by the national legislature, still much remains within the competence of a Member State. 
The role of the national legislature is to create the relation between national conditions and the EU system. It should be noted that the ETS Act combines provisions of the Phase II with the provisions of the Phase III. As a matter of fact, the implementation of provisions of the Directive 2009/29 and other provisions of the Community law relating to the functioning of the ETS into the Polish legal system by the Act of 28 April 2011 is a work in progress. The issues to be regulated include the terms of purchase of missing allowances at auctions, rules for allocation of free allowances (under Articles 10(a) and 10(c) of the Directive 2009/29/EC) and the way of spending funds received from the sale of emission allowances. Much as these changes to the Act are absolutely necessary, it seems hardly possible that this will be done before the end of the second accounting period. It can be expected that it will rather be the period of the creative interpretation of the law and the close cooperation between the national administration and the government in terms of negotiating_the scope of application and enforcement of the provisions of law. 